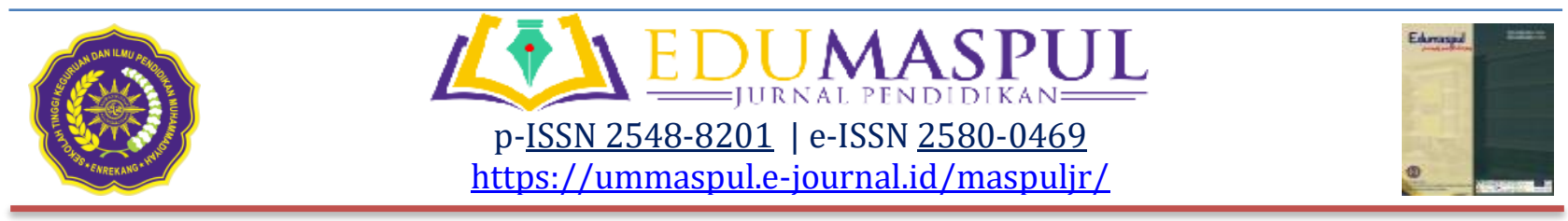

\title{
A Case study of Classroom management at English Education Deparment of STKIP Muhammadiyah Enrekang: Students's Team Work Preference
}

\author{
Umiyati Jabri' ${ }^{1}$, Ita Sarmita Samad ${ }^{2}$ \\ 1,2English Education Department, STKIP Muhammadiyah Enrekang, Indonesia \\ $\triangle$ Corresponding email: ${ }^{1} \underline{\text { umiyatijabri@gmail.com; } 2 \text { itaneverendita@gmail.com }}$
}

\begin{abstract}
This study aims to identify students' teamwork models that the students prefer in the teaching and learning process in the classroom For this study, a 10-item possitive-negative statements questionnaire was constructed and gave to the students. The questionnaire was completed by 60 students. From the data analyzing using a Likert scale, the result of the questionnaire calculation showed that the students' average is about 27,6 . This result is in undecided categories as stated on the Likert scale. It means that the students cannot decide their teamwork model preferences from teamwork models that lecturers applied in teaching and learning English in the classroom. Thus, it can be assumed that whatever the teamwork model implemented by lecturers in the teaching and learning process in the classroom, the students can receive it. In other words, students still have a positive attitude toward whatever the teamwork model implemented by the lecturers in the teaching and learning process in the classroom.
\end{abstract}

Keywords: Team work model, Classroom managent, Preference

\begin{abstract}
Abstrak. Penelitian ini bertujuan untuk mengidentifikasi model pengelompokan yang lebih disukai siswa dalam proses belajar mengajar di kelas. Untuk penelitian ini, kuesioner pernyataan positif dan negatif yang terdiri dari 10-item positif dibuat dan diberikan kepada siswa. Kuesioner diisi oleh 60 siswa. Dari analisis data menggunakan skala Likert, hasil perhitungan kuesioner menunjukkan bahwa nilai rata-rata siswa adalah sekitar 27, 6. Hasil ini berada dalam kategori tidak pasti seperti yang dinyatakan dalam skala likert. Ini berarti bahwa siswa tidak dapat memutuskan preferensi model kerja tim mereka dari model kerja tim yang diterapkan dosen dalam pengajaran dan pembelajaran bahasa Inggris di kelas. Jadi, dapat diasumsikan bahwa apa pun model kerja tim yang diterapkan oleh dosen dalam proses belajar mengajar di kelas, siswa dapat menerimanya, atau dengan kata lain, siswa masih memiliki sikap positif terhadap apa pun model kerja tim yang diterapkan oleh dosen. apa pun model kerja tim siswa yang diterapkan oleh dosen dalam proses belajar mengajar di kelas.
\end{abstract}

Kata Kunci: Model Kerja Tim, Manajemen Kelas, Preferensi 


\section{INTRODUCTION}

To become a developed, strong, and prosperous country, Quality of human resources are a very important aspect to be considered. Efforts to improve the quality of human resources cannot be separated from the problem of national education. According to Mulyasa (2006: 3) "There are at least three main requirements that must be considered in the development of education so that they can contribute to the improvement of the quality of human resources, namely: (1) building facilities, (2) quality books, (3) education and teacher professional.

Professional teacher is characterized by a teacher who is able to manage the class well. According to Permendiknas No 16/2007, the teacher must have four competences; pedagogical competence, personal competence, social competence, and professional competence. Professional teachers should conduct an analysis of learners characteristics, prepare the design of learning process according to the characteristics of learners and teaching materials, create a conducive atmosphere to the learning process, implement a conducive teaching and learning process for students to learn, and choose the best medium of learning media for students (Jabri, 2012). In class, all aspects of teaching education meet and process. Teachers with all their abilities, students with all their backgrounds and individual traits; curriculum with all its components; and material and sources of learning with all the subjects met and combined and interacted in class.

Even the results teaching and learning process are largely determined by what happens in the classroom. Therefore the class should be managed professionally. Some experts have defined the definition of classroom. According to Ian Tudor
(2001:43) classroom is a controlled learning environment a place where students work on the language according to a carefully designed learning programme under the supervision and guidance of a trained teacher. Ahmadi (1995: 1) states "Classroom management is all efforts to conduct an effective and enjoyable teaching and learning atmosphere in the classroom and can motivate students to study well according to their abilities". Classroom management is an effort to regulate the activities of the teaching and learning process systematically by the teacher. The effort leads to the preparation of learning materials, preparation of facilities and visual aids, arrangement of study rooms, realizing learning conditions / conditions of learning and time management so that the teaching and learning process runs well and the goals of teaching can be achieved.

At the campus, the interaction between lecturers and the students, students in this case have become adult learners from psychological perspective; the lecturers still also need to consider the management of interaction to be used in teaching process. This is very important because there are many individual differences that students have in studying English. Those differences such are age, motivation, interest, attitude, intelligence, learning style, learning strategy, etc. Jinwei Ma (2008) stated in teacher discussion forum that: "Group learning can create a favorable atmosphere for the students to develop their imagination and creativity. They will feel free to practice their oral English. They can not only help each other to improve incorrect pronunciation or to rectify grammatical mistakes but also draw on collective wisdom and absorb all the useful ideas." 
Therefore, lecturer must consider about the principles of students grouping model given that aim not only to facilitate students to understand the material but also to build emotional relationship between them in many cases of knowledge and skills in English as a foreign language. There are some principles that can be used in students' team work and giving assignment to the students such as: (1) human relation: grouping principle that allows students to have their group member that they like (who likes whom); (2) ability/achievement: grouping principle based on the students' ability (good, average, poor, and mixed ability); According to Jennifer Waqaman (2008), with this method, the lecturers would look at the ability of each student, and place him/her in a group with other students with the same ability (3) sex: grouping students based on the gender (male, female, male-female); (4) individual differences: grouping model based on students' age, motivation, attitude, learning style, learning strategy, and brain dominant; According to Herbert \& Eve (1977), for most people language appears to be located in the left hemisphere of the brain. and (5) no obvious principle: students grouping model based on the number in attendance list or counting until certain number and find the group member based on the same mentioned number.

The application of those principles must be appropriate with students' team work which based on classroom management. Harmer $(1991,243)$ argued that there are four form of student grouping that teacher/lecturer can apply in instructional those are (1) lockstep: this grouping form is called traditional teaching situation or teacher-center learning where lecturer became a main source. All the students are working with the lecturer. In this case, lecturer has right to control the class by using lecturer-students interaction pattern. The weaknesses of this grouping form are students get little chance to practice or to talk at all and students are easy to be bored, (2) pair work: this grouping form is very effective to increase students' participation in using English, (3) group/ team: this grouping form can also give a lot of chance to the students to practice their English where in this form students feel more relax than work in pairs, (4) individual: in this grouping form, students are free to explore themselves in using their English and can relax from outside pressure (provided there is no time limit or competitive element).

Based on the pre-observation, the researcher found that there are four models of team work that lectures apply in the teaching and learning process at English Education Deparment of STKIP Muhammadiyah Enrekang, namley, lockstep, pair/partner, group, and individual. therefore, the researcher felt excited to conduct a research entitle " $A$ Case study at English Education Deparment of STKIP Muhammadiyah Enrekang: Students's Team Work Preference

\section{METHODOLOGY}

The method of this research was a descriptive research. Descriptive research descriptive research determines and reports the way the things are (Gay, 1987). Descriptive research was aimed to comprehend and enlighten the existing phenomena experienced by the subject of the research such as attitude, perception, motivation, action, etc, in holistic way, and by describing it in words and language, on expected particular context and by using such kinds of accepted method. Descriptive data was usually collected by 
questionnaire surveys, telephone surveys, interviews, or observation. In this research, the researcher used questionnaires to collect the data. After collecting the data, the researcher analyzed the data qualitatively. In conducting the research, the reserach did some steps, namely collecting the data, reviewing the data, organizing the data for analysis,developing the codes, coding the data, finding themes, patterns, and relationships, summarizing the data, discussing the data and drawing the conclusion.

This research would be conducted in STKIP Muhammadiyah Enrekang. The sample was all students of English Department at STKIP Muhammadiyah Enrekang. The instrument in this research is a questionnaire prepared by the researcher. The questionnaire consists of 5 positive statements and 5 negative statements. Those categories are as follows:

Table 1. Scoring categories

\begin{tabular}{ll}
\hline Scores & Categories \\
\hline $43-50$ & Strongly Like \\
\hline $35-42$ & Like \\
\hline $27-34$ & Undecided \\
\hline $19-26$ & Dislike \\
\hline $10-18$ & Strongly Dislike \\
\hline
\end{tabular}

The students' preferences about the students grouping model that lecturers apply in teaching and learning was determined by those categories through the calculation of mean score.

The procedure of collecting data covered several steps. The researcher started by distributing the questionnaires to the students to gather information about their grouping preference and giving a brief explanation about the problems factors discussed in the research.

\section{RESULT AND DISCUSSION}

Item 1: Grouping student based on human relation principle in the form of lockstep.

Table 2. Results of questionnare number 1

\begin{tabular}{lcc}
\hline \multicolumn{1}{c}{ Item } & Total & Percentage \\
\hline Strongly agree & 3 & 3.3 \\
\hline Agree & 40 & 44.4 \\
\hline Undecided & 22 & 24.4 \\
\hline Disagree & 21 & 23.3 \\
\hline Strongly Disagree & 4 & 4.4 \\
\hline Total & 90 & 100 \\
\hline
\end{tabular}

Item 2: Grouping student that is not based on human relation principle in the form of lockstep.

Table 3. Results of questionnare number 2

\begin{tabular}{lcc}
\hline \multicolumn{1}{c}{ Item } & Total & Percentage \\
\hline Strongly agree & 4 & 4.4 \\
\hline Agree & 26 & 28.9 \\
\hline Undecided & 26 & 28.9 \\
\hline Disagree & 32 & 35.6 \\
\hline $\begin{array}{l}\text { Strongly } \\
\text { Disagree }\end{array}$ & 2 & 2.2 \\
\hline Total & 90 & 100 \\
\hline
\end{tabular}

Item 3: Grouping student based on ability principle in the form of pair.

Table 4. Results of questionnare number 3

\begin{tabular}{lcc}
\hline Item & Total & Percentage \\
\hline Strongly agree & 4 & 4.4 \\
\hline Agree & 18 & 20 \\
\hline Undecided & 14 & 15.6 \\
\hline Disagree & 45 & 50 \\
\hline Strongly & 9 & 10 \\
Disagree & & \\
\hline Total & 90 & 100 \\
\hline
\end{tabular}


Item 4: Grouping student that is not based on ability principle in the form of pair.

Table 5. Results of questionnare number 4

\begin{tabular}{lcc}
\hline \multicolumn{1}{c}{ Item } & Total & Percentage \\
\hline Strongly agree & 6 & 6.7 \\
\hline Agree & 44 & 48.9 \\
\hline Undecided & 12 & 13.3 \\
\hline Disagree & 24 & 26.7 \\
\hline $\begin{array}{l}\text { Strongly } \\
\text { Disagree }\end{array}$ & 4 & 4.4 \\
\hline Total & 90 & 100 \\
\hline
\end{tabular}

Item 5: Grouping student based on sex principle in the form of group.

Table 6. Results of questionnare number 5

\begin{tabular}{lcc}
\hline \multicolumn{1}{c}{ Item } & Total & Percentage \\
\hline Strongly agree & 4 & 4.4 \\
\hline Agree & 10 & 11.1 \\
\hline Undecided & 6 & 6.7 \\
\hline Disagree & 62 & 68.9 \\
\hline $\begin{array}{l}\text { Strongly } \\
\text { Disagree }\end{array}$ & 8 & 8.9 \\
\hline Total & 90 & 100 \\
\hline
\end{tabular}

Item 6: Grouping student that is not based on sex principle in the form of group.

Table 7. Results of Questionnare number 6

\begin{tabular}{lcc}
\hline \multicolumn{1}{c}{ Item } & Total & Percentage \\
\hline Strongly agree & 5 & 5.6 \\
\hline Agree & 57 & 63.3 \\
\hline Undecided & 10 & 11.1 \\
\hline Disagree & 17 & 18.8 \\
\hline $\begin{array}{l}\text { Strongly } \\
\text { Disagree }\end{array}$ & 1 & 1.1 \\
\hline Total & 90 & 100 \\
\hline
\end{tabular}

Item 7: Grouping student based on individual differences.

Table 8. Results of questionnare number 7

\begin{tabular}{lcc}
\hline \multicolumn{1}{c}{ Item } & Total & Percentage \\
\hline Strongly agree & 2 & 2.2 \\
\hline Agree & 15 & 16.7 \\
\hline Undecided & 9 & 10 \\
\hline Disagree & 56 & 62.2 \\
\hline $\begin{array}{l}\text { Strongly } \\
\text { Disagree }\end{array}$ & 8 & 8.9 \\
\hline Total & 90 & 100 \\
\hline
\end{tabular}

Item 8: Grouping student that is not based on individual differences.

Table 9. Results of questionnare number 8

\begin{tabular}{lcc}
\hline \multicolumn{1}{c}{ Item } & Total & Percentage \\
\hline Strongly agree & 8 & 8.9 \\
\hline Agree & 55 & 61.1 \\
\hline Undecided & 11 & 12.2 \\
\hline Disagree & 10 & 11.1 \\
\hline $\begin{array}{l}\text { Strongly } \\
\text { Disagree }\end{array}$ & 6 & 6.7 \\
\hline Total & 90 & 100 \\
\hline
\end{tabular}

Item 9: Grouping student based on no obvious principle.

Table 10. Results of questionnare number 9

\begin{tabular}{lcc}
\hline \multicolumn{1}{c}{ Item } & Total & Percentage \\
\hline Strongly agree & 6 & 6.7 \\
\hline Agree & 34 & 37.8 \\
\hline Undecided & 18 & 20 \\
\hline Disagree & 24 & 26.7 \\
\hline $\begin{array}{l}\text { Strongly } \\
\text { Disagree }\end{array}$ & 8 & 8.9 \\
\hline Total & 90 & 100 \\
\hline
\end{tabular}


Item 10: Grouping student that is not based on any obvious principle.

Table 11. Results of questionnare number 10

\begin{tabular}{lcc}
\hline \multicolumn{1}{c}{ Item } & Total & Percentage \\
\hline Strongly agree & 6 & 6.7 \\
\hline Agree & 34 & 37.8 \\
\hline Undecided & 18 & 20 \\
\hline Disagree & 24 & 26.7 \\
\hline $\begin{array}{l}\text { Strongly } \\
\text { Disagree }\end{array}$ & 8 & 8.9 \\
\hline Total & 90 & 100 \\
\hline
\end{tabular}

$$
\begin{aligned}
& =\frac{\Sigma \mathrm{X}}{\mathrm{N}} \\
& =\frac{2.484}{90} \\
& =27.6
\end{aligned}
$$

Based on the data above the average of the result from Questionnare is 27.6

\section{DISCUSSION}

The result of questionnaire calculation showed that the students' average is about 27,6 . This result is in undecided categories as stated in likert scale. It means that the students cannot decide their team work lecturers applied in teaching and learning English in the classroom. So, it can be assumed that whatever the team work model implemented by lecturers in teaching and learning process in the classroom, the students can receive it, or in other words, students still have positive attitude toward whatever the grouping model implemented by the lecturers.

Based on the explanation above, it can be concluded that whatever the team work model implemented by the lecturers in the teaching and learning process in the classroom, the students can receive it. Whatever the models implemented, those are the models that students prefer in learning process. In other words, students are hesitant to decide which one of the grouping model that they prefer than others that lecturers can use as a consideration in managing the classroom that they are going to apply during teaching and learning process. Because most of the lecturers only apply student grouping model based on human relation and no obvious principle in teaching and learning process in the classroom.

\section{CONCLUSION}

This research could be concluded that whatever the team work model implemented by the lecturers in the teaching and learning process in the classroom, the students can receive it. Whatever the models implemented, those are the models that students prefer in learning process. In other words, students are hesitant to decide which one of the grouping model that they prefer than others that lecturers can use as a consideration in managing the classroom that they are going to apply during teaching and learning process. Because most of the lecturers only apply student grouping model based on human relation and no obvious principle in teaching and learning process in the classroom.

Since the researcher thinks that the implementation of various kinds of student grouping can effect students' motivation, attitude, and interest toward English, the researcher would be pleased if the next researchers want to conduct researches related to this topic to find out the students grouping model that most of the students prefer in teaching and learning process in the classroom. 


\section{References}

[1] Clark, Herbert, \& Clark, eve. (1977). Psychology and language. Usa: Harcourt brace Jovanovich.

[2] Gall, M, D., Gall, J. P., \& Borg, W. R. (2005). Educational Research an Introduction,

[3] Gay, L.R. (1987). Educational Research: Competencies for Analysis and Application (4th Ed). Ohio: Merrill.

[4] Harmer, Jeremy. (1991). The Practice of English Language Teaching. London: Longman.

[5] Ismail, Yunus Busa, Tini. (2018). Parental involvement in fostering the character of children's discipline at elementary school. Jurnal Pendidikan Progresif, Vol 8, No 2.2 DOI: http://dx.doi.org/10.23960/ipp.v8. i2.201807

[6] Ismail, Elihami, Mustakim. (2019). Students' Perceptions of the Benefits of Mobile Polling Technology in Teaching and Learning in College: Implications of Students' Participation and academic Performance. Jurnal Pendidikan Progresif, Vol 9, No 1. DOI:

http://dx.doi.org/10.23960/jpp.v9. $\underline{\mathrm{i} 1.201912}$

[7] Jabri, U. (2017). The Profile of English Teachers' Professional Competence and Students'
Achievement at SMA Negeri 1 Enrekang. Edumaspul: Jurnal Pendidikan, 1(1), 61-77. https://doi.org/10.33487/edumas pul.v1i1.45

[8] Ma, Jinwei. (2008). The Importance of Group Learning in Language Teaching. Retrieved from http://forums.eslcafe.com/teacher Lviewtopic.php

[9] Mulyasa, E. (2005). Menjadi Guru Profesional Mennciptakan Pembelajaran Kreatif dan Menyenagkan. Bandung:n remaja Rosdakarya.

[10] Tudor, Ian. (2001). The Dynamics of the Language Classroom. Cambridge : Cambridge University Press.

[11] Undang-Undang Republik Indonesia. (2007). Peraturan Menteri Pendidikan Nasional Republik Indonesia Nomor 16 Tahun 2007 Tentang Standar Kualifikasi Akademik Dan Kompetensi Guru. Jakarta: Depdiknas

[12] Waqaman, Jennifer. (2008). Student Grouping in the Classroom: Four Ways to Divide Your Class for Learners. Retrieved from http://teachertipstraining.suite101 .com/article.cfm/student grouping in the classroom. 